\title{
PENGEMBANGAN SISTEM INFORMASI GEOGRAFIS PELAPORAN KERUSAKAN DAN KEGIATAN PENINGKATAN RUAS JALAN DI KOTA BANDAR LAMPUNG
}

\author{
${ }^{1}$ Dipa Fitra \\ ${ }^{1}$ Jurusan Ilmu Komputer, Fakultas Matematika dan Ilmu Pengetahuan Alam, \\ Universitas Lampung, Lampung, Indonesia \\ e-mail : dipafitra@gmail.com
}

\begin{abstract}
Roads are one of the factors that support the development of the region as a whole. Management of reporting of damaged roads at Bandar Lampung Public Works Agency still uses paper documents and the dissemination of road information to the community is not good enough. Therefore, in this study a geographic information system (GIS) will be developed as an innovation to simplify the process of reporting damaged roads to be more efficient and to better disseminate information to the public. GIS is a system designed to work with data that is spatially referenced or geographic coordinates. The design of this system uses Use Case, Activity Diagram, Sequence Diagram, and Class Diagram. The system implementation uses Google Maps API and is developed using PHP and Javascript programming languages and MySQL database. Based on the results of the analysis of system testing, the average value of the overall test obtained was 3,78. Which is looked Based on interval table of the Likert scale, the final value of test shows that GIS was successful. The results of the black box test also show that each function in each menu on the system has been running according to the procedure.
\end{abstract}

Keywords: API; Damaged Road; GIS; Mysql

\section{PENDAHULUAN}

Jalan merupakan salah satu faktor pendukung perkembangan wilayah secara menyeluruh. Tersedianya infrastruktur jaringan jalan yang memadai merupakan salah satu modal besar untuk meningkatkan kegiatan masyarakat di suatu daerah.Salah satu contoh suatu penelitian tentang jalan adalah SIG kerusakan ruas jalan di kota Yogyakarta. Penelitian tersebut bertujuan untuk mencari solusi dalam pencarian dan pembaharuan data lokasi jalan yang telah disurvey yang akan digunakan untuk perencanaan perbaikan dan perawatan jalan yang diprioritaskan. Penelitian tersebut dilakukan karena pada Dinas Pekerjaan Umum Kota Yogyakarta, dalam pengelolaan data kondisi jalan masih menggunakan dokumen kertas [1].

Sama halnya dengan permasalahan di kota Bandar Lampung, sistem pelaporan dan pengelolaan jalan rusak masih menggunakan dokumen kertas. oleh karena itu diperlukan solusi dalam pencarian dan pembaharuan data lokasi jalan yang telah disurvey agar dapat digunakan untuk perencanaan perbaikan dan perawatan jalan. SIG merupakan sistem yang dirancang untuk bekerja dengan data yang tereferensi secara spasial atau koordinat-koordinat geografi. SIG memiliki kemampuan untuk melakukan pengolahan data dan melakukan operasi-operasi tertentu dengan menampilkan dan menganalisa data, SIG memakai fitur Google Maps API untuk mengambil lokasi secara online [2].

API atau Application Programming Interface merupakan suatu dokumentasi yang terdiri dari interface, fungsi, kelas, struktur dan sebagainya untuk membangun sebuah perangkat lunak. Dengan adanya API ini, maka memudahkan programmer untuk membuat suatu software untuk kemudian dapat dikembangkan atau diintegrasikan dengan perangkat lunak yang lain. API dapat dikatakan sebagai penghubung suatu aplikasi dengan aplikasi lainnya.[3] 


\subsection{Rumusan Masalah}

Rumusan masalah dari penelitian ini adalah bagaimana membangun sistem informasi geografis (SIG) pelaporan kerusakan dan kegiatan peningkatan jalan di kota Bandar Lampung yang dapat menampilkan dan memberikan informasi jalan rusak serta menjadi media penyimpanan dan publikasi Informasi kerusakan jalan di kota Bandar Lampung.

\subsection{Tujuan Penelitian}

Tujuan dari penelitian ini adalah merancang dan membangun suatu sistem informasi geografis berbasis web untuk membantu dalam proses pelaporan kerusakan jalan dan menampilkan hasil peningkatan ruas jalan di kota Bandar Lampung.

\section{METODOLOGI PENELITIAN}

Penelitian dilakukan berdasarkan diagram alir metodologi yang disajikan pada Gambar 1.

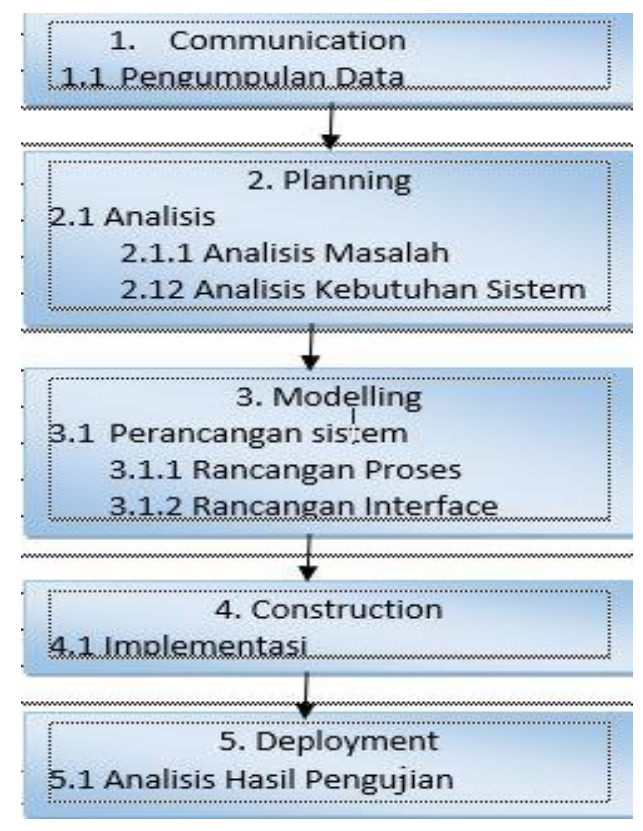

Gambar 1. Tahapan Penelitian

\subsection{Pengumpulan Data}

Pengumpulan data pada penelitian ini dengan wawancara langsung dengan Kepala Seksi Bagian Perencanaan Dinas PU Kota Bandar Lampung. Data yang diperoleh berupa data jalan rusak berdasarkan survey untuk tahun 2016.

\subsection{Analisis}

Pada tahap ini terbagi menjadi dua yaitu analisis masalah dan analisis kebutuhan sistem yaitu sebagai berikut. 2.2.1. Analisis Masalah

Dinas Pekerjaan Umum (PU) Kota Bandar Lampung menghadapi permasalahan terkait proses pelaporan jalan. Berdasarkan data dari Dinas PU Bandar Lampung, ruas jalan kota Bandar Lampung mendapat 2 perlakuan yaitu pemeliharaan dan peningkatan. Proses pemeliharaan ditunjukkan untuk tingkat kerusakan ringan sedangkan proses peningkatan ditunjukkan untuk jalan dengan tingkat kerusakan menengah dan berat. Dinas PU mengolah dokumen dan meyimpan data dalam media kertas serta file pada komputer personal. Proses penyimpanan tersebut terlihat kurang efektif dan aman untuk jangka panjang. Untuk 
mengatasi kekurangan tersebut, maka telah dirancang skema baru untuk proses pelaporan, skema dibuat dalam bentuk use case Diagram. Use case yang telah dirancang ditunjukkan pada Gambar 2.

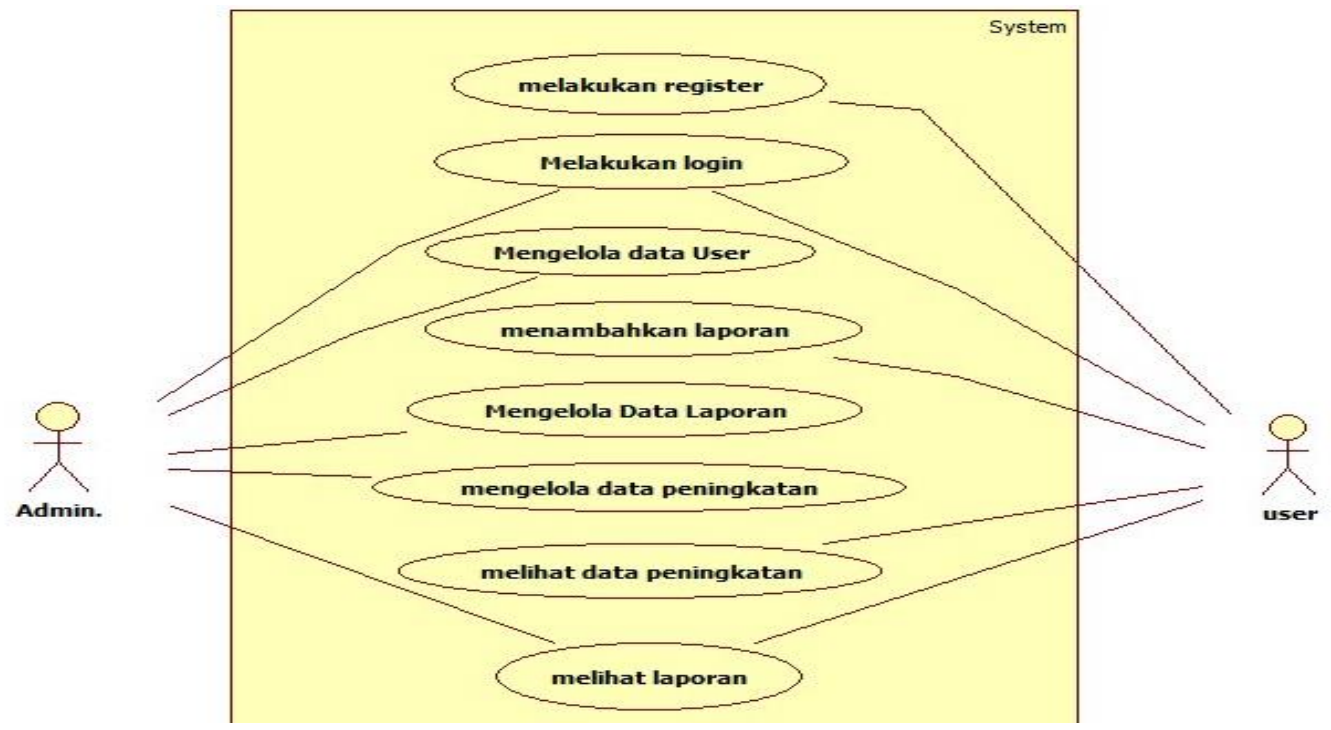

Gambar 2. Use Case Diagram

Gambar tersebut menjelaskan interaksi antara use case dan aktor. Aktor merupakan objek yang berinteraksi dengan sistem yang sedang dibangun. Terdapat 8 interaksi yang didalamnya terdapat 2 aktor yang berperan yaitu Admin dan User. Use case digunakan untuk menggambarkan fungsionalitas sistem atau persyaratanpersyaratan yang harus dipenuhi oleh sistem dari pandangan $u s e r$.

\subsubsection{Analisis Kebutuhan Sistem}

Software yang digunakan dalam Pengembangan Sistem sistem antara lain :

1. Sistem operasi Windows 10 Pro 64 Bit

2. XAMPP Server Version 3.2.1

3. Web browser Chrome

4. Google Maps

5. Microsoft Visio 2003

6. Star UML

7. Notepad++

Hardware yang digunakan dalam penggunaan sistem ini sebagai berikut.
1. Processor
: Intel Core i5 $2430 \mathrm{~m}-2.4 \mathrm{Ghz}$
2. RAM
: 4 GB DDR3
3. Harddisk
: 500 GB SATA
4. OS
: Windows 10 Pro
5. System Type : 64-bit Operating System

\subsection{Perancangan Sistem}

Perancangan sistem dibuat untuk memberikan gambaran yang jelas dan menghasilkan rancangan bangun yang lengkap kepada pemograman komputer dan ahli-ahli teknik lainnya yang terlibat dalam pengembangan atau pembuatan sistem.

\subsubsection{Rancangan Proses}

Rancangan proses sistem digambarkan dalam bentuk activity diagram. Activity diagram yang dibuat pada penelitian ini disesuaikan dari setiap proses utama yang ada pada use case diagram. Contoh salah satu proses Activity diagram ditampilkan pada Gambar 3. 
(C2021 Ilmu Komputer Unila Publishing Network all rights reserved

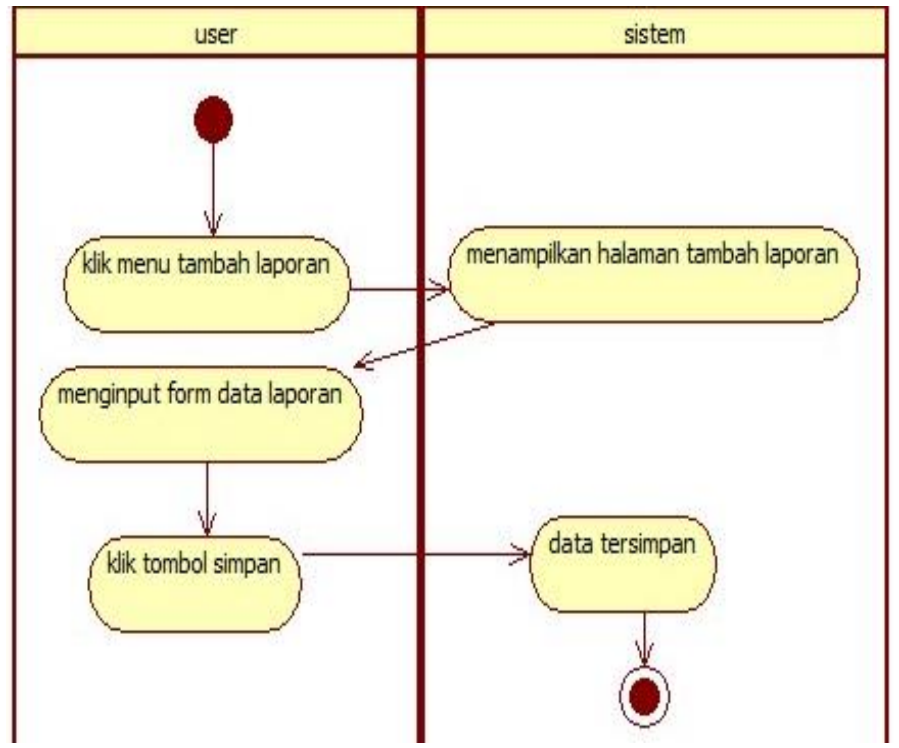

Gambar 3. Use Case Diagram Tambah Laporan

Rancangan proses sistem selanjutnya digambarkan dengan menggunakan sequence diagram. Sequence Diagram atau interaksi antar objek pada penelitian ini dibuat berdasarkan setiap proses utama yang ada pada usecase diagram. Contoh salah satu proses Sequence diagram ditampilkan pada Gambar 4.

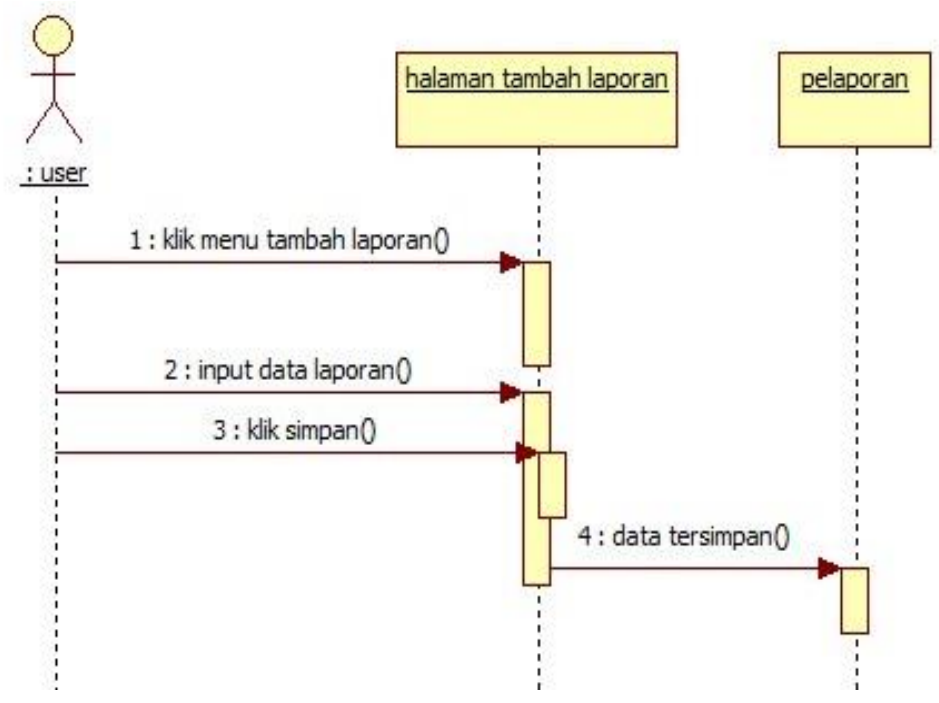

Gambar 4. Activity Diagram Tambah Laporan

Class Diagram juga dirancang dalam sistem ini. Class Diagram merupakan gambaran struktur sistem dari segi pendefinisian kelas-kelas yang dipakai untuk membangun sistem. Class Diagram pada sistem ini dapat dilihat pada Gambar 5. 


\begin{tabular}{|l|}
\hline \multicolumn{1}{|c|}{ pengguna } \\
\hline -id \\
+nama \\
+email \\
+username \\
+password \\
+no_ktp \\
+kelamin \\
+no_hp \\
rtgl_lahir \\
+agama \\
+alamat \\
+sts_kwn \\
+pekerjaan \\
+photo \\
+level \\
\hline
\end{tabular}

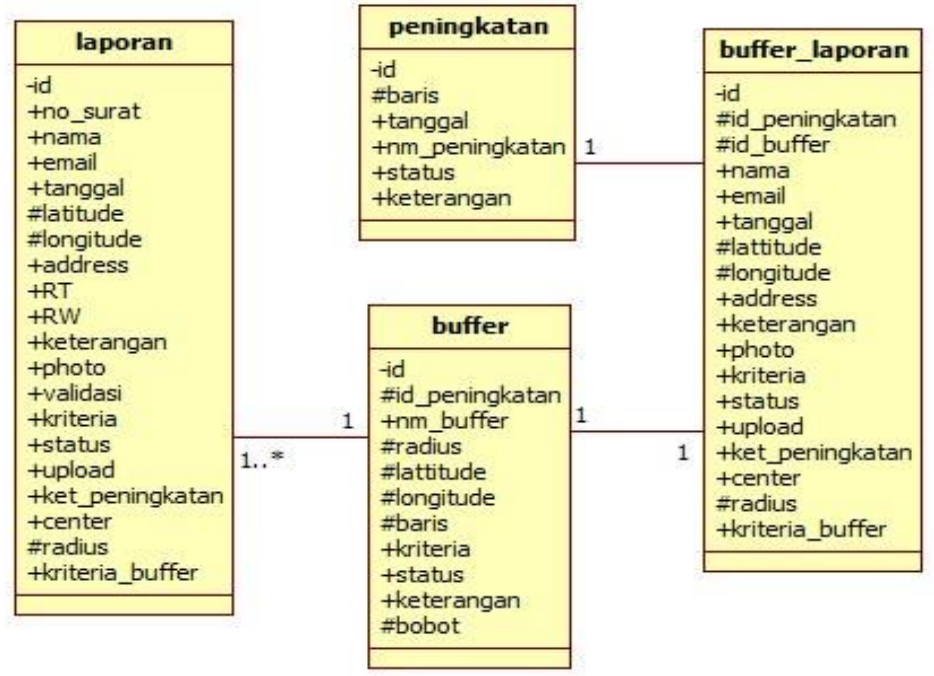

Gambar 5. Class Diagram

\subsubsection{Rancangan Interface}

Rancangan Interface sistem ini dibagi menjadi tiga yaitu halaman utama, halaman Admin, dan halaman User. Halaman utama terdapat beberapa menu yaitu beranda, masuk, jalan rusak, dan tentang. Halaman utama ditampilkan pada Gambar 6.

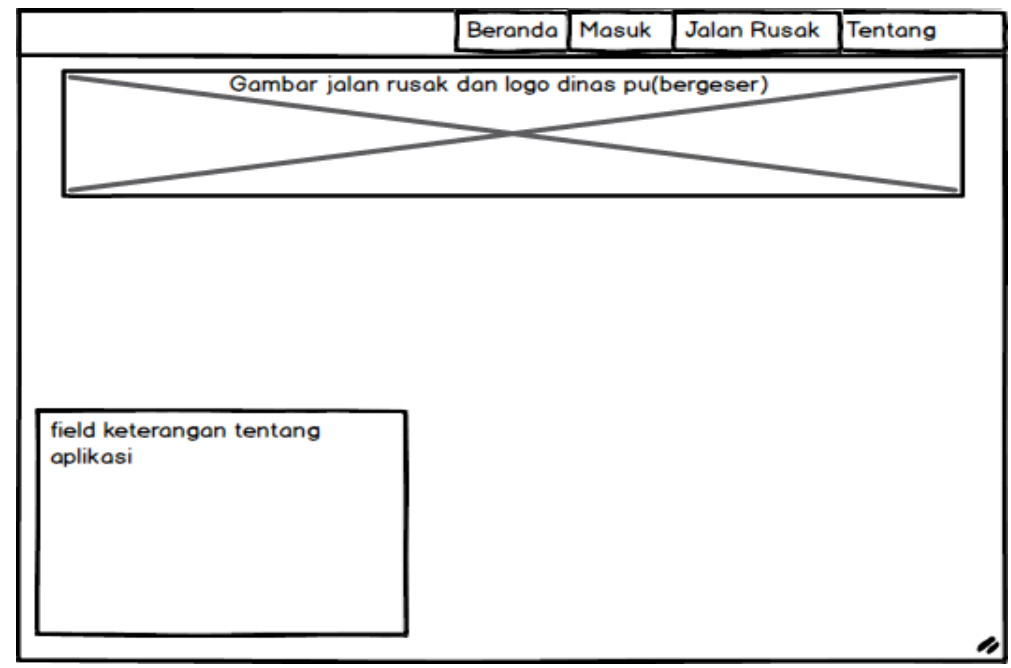

Gambar 6. Rancangan Interface Sistem

\section{HASIL DAN PEMBAHASAN}

\subsection{Implementasi}

Pada tahap implementasi dilakukan penerapan hasil rancangan aplikasi yang telah dibuat pada proses perancangan aplikasi. Hasil dari tahapan implementasi pada penelitian ini adalah sebuah aplikasi pengembangan SIG pelaporan dan proses peningkatan jalan di kota Bandar Lampung pembuatan berbasis web dan juga berbasis mobile android yang sesuai dengan tujuan penelitian. Tampilan Hasil Implementasi Rancangan interface disajikan pada Gambar 7 dan Gambar 8. 
(C2021 Ilmu Komputer Unila Publishing Network all rights reserved

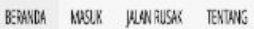

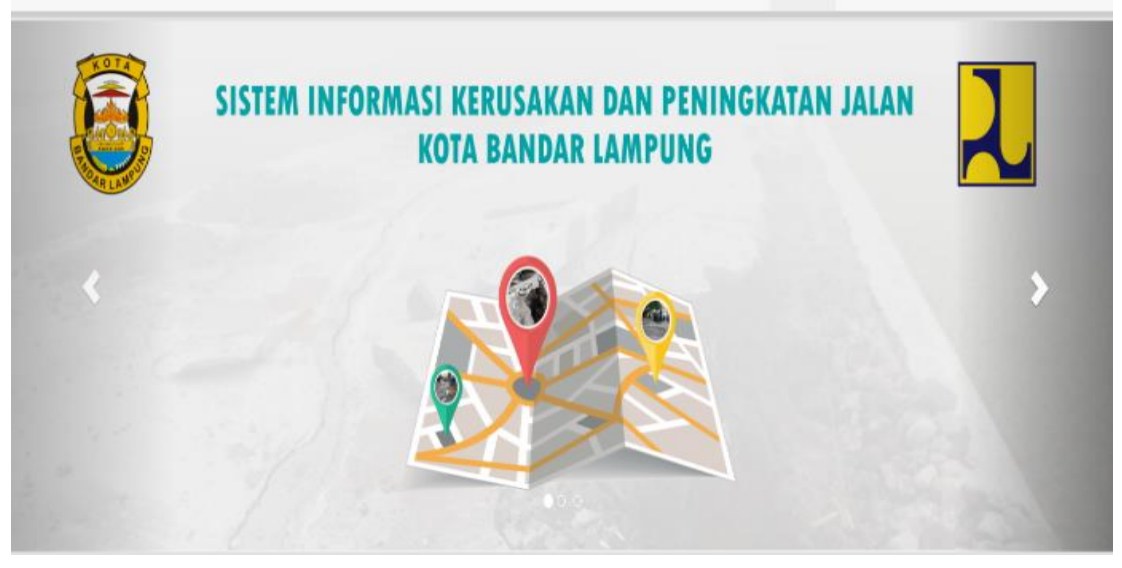

Gambar 7. Halaman Utama Sistem Web

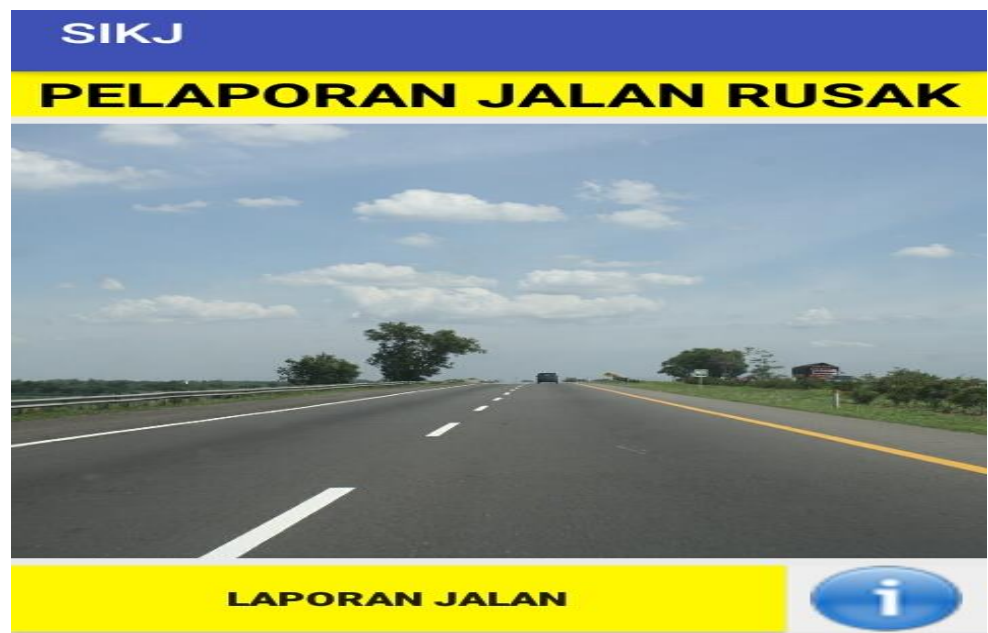

Gambar 8. Halaman Utama Aplikasi Mobile

\subsection{Analisis Hasil Pengujian}

Analisis dilakukan dengan metode non fungsional berupa kuesioner yang menggunakan perhitungan skala likert, kuesioner diberikan kepada 15 orang. koresponden Berikut adalah Hasil dari proses pengujian tersebut.

\subsubsection{Variabel User Interface}

Pengujian pada Variabel user interface ini menggunakan kuesioner yang berisi beberapa Pernyataan.kuesioner yang diberikan kepada 15 orang koresponden, Hasil pengujian User Interface disajikan pada Tabel 1 dan Tabel 2. 
(C2021 Ilmu Komputer Unila Publishing Network all rights reserved

Tabel 1. Jumlah penilaian kategori User Interface pada 15 koresponden

\begin{tabular}{|c|c|c|c|c|c|c|c|c|}
\hline \multirow{2}{*}{ No } & \multirow{2}{*}{ Kriteria Penilaian } & \multicolumn{4}{|c|}{ Kategori Penilaian } & \multicolumn{2}{|c|}{ Jumlah penilaian } & \multirow{2}{*}{ Total } \\
\hline & & 5 & 4 & 3 & 2 & 1 & & \\
\hline 1 & $\begin{array}{l}\text { Kesesuaian warna } \\
\text { background dan } \\
\text { teks pada sistem }\end{array}$ & 2 & 11 & 2 & - & \multicolumn{2}{|c|}{$(5 \times 2)+(4 \times 11)+(3 \times 2)$} & 60 \\
\hline 2 & $\begin{array}{l}\text { Pemilihan font } \\
\text { pada sistem }\end{array}$ & 3 & 6 & 6 & - & \multicolumn{2}{|c|}{$(5 \times 3)+(4 \times 6)+(3 \times 6)$} & 57 \\
\hline 3 & $\begin{array}{l}\text { Kualitas gambar } \\
\text { pada sistem }\end{array}$ & 2 & 5 & 8 & - & \multicolumn{2}{|c|}{$(5 \times 2)+(4 \times 5)+(3 \times 8)$} & 54 \\
\hline 4 & $\begin{array}{l}\text { Kejelasan informasi } \\
\text { menu pilihan }\end{array}$ & 2 & 9 & 4 & - & \multicolumn{2}{|c|}{$(5 \times 2)+(4 \times 9)+(3 \times 4)$} & 58 \\
\hline \multirow{2}{*}{\multicolumn{9}{|c|}{$\begin{array}{l}\text { Pernyataan diberikan dalam lima pilihan skala untuk kategori penilaian, yaitu: } 5=\text { sangat baik, } 4=\text { baik, } \\
\text { cukup baik, } 2=\text { kurang baik, dan } 1=\text { tidak baik. }\end{array}$}} \\
\hline & & & & & & & & \\
\hline No & Kriteria Penilaian & \multicolumn{4}{|c|}{ Total penilaian } & Koresponden & Rata-Rata & Kategori \\
\hline 1 & $\begin{array}{l}\text { Kesesuaian warna } \\
\text { background dan teks } \\
\text { pada sistem }\end{array}$ & \multicolumn{4}{|c|}{60} & 15 & 4 & Baik \\
\hline 2 & $\begin{array}{l}\text { Pemilihan font pada } \\
\text { sistem }\end{array}$ & \multicolumn{4}{|c|}{57} & 15 & 3,8 & Baik \\
\hline 3 & $\begin{array}{l}\text { Kualitas gambar pada } \\
\text { sistem }\end{array}$ & \multicolumn{4}{|c|}{54} & 15 & 3,6 & Baik \\
\hline 4 & $\begin{array}{l}\text { Kejelasan informasi } \\
\text { menu pilihan }\end{array}$ & \multicolumn{4}{|c|}{58} & 15 & 3,8 & Baik \\
\hline \multicolumn{6}{|c|}{ Rata-Rata Seluruh Kriteria } & & 3.816667 & Baik \\
\hline
\end{tabular}

\subsubsection{Variabel Kinerja Sistem}

Pengujian pada variabel kinerja sistem menggunakkan kuesioner yang berisi beberapa Pernyataan.kuesioner diberikan kepada 15 orang koresponden. Hasil pengujian kinerja sistem disajikan pada Tabel 3 dan Tabel 4. 
(C2021 Ilmu Komputer Unila Publishing Network all rights reserved

Tabel 3. Jumlah penilaian kategori kinerja sistem pada 15 koresponden

\begin{tabular}{|c|c|c|c|c|c|c|c|c|}
\hline \multirow{2}{*}{ No } & \multirow{2}{*}{ Kriteria Penilaian } & \multicolumn{5}{|c|}{ Kategori Penilaian } & \multirow[t]{2}{*}{ Jumlah penilaian } & \multirow{2}{*}{ Total } \\
\hline & & 5 & 4 & 3 & 2 & 1 & & \\
\hline 1 & $\begin{array}{l}\text { Respon sistem dalam } \\
\text { Pmenampilkan tiap } \\
\text { menu pada sistem }\end{array}$ & 2 & 8 & 5 & - & - & $(5 \times 2)+(4 \times 11)+(3 \times 2)$ & 57 \\
\hline 2 & $\begin{array}{l}\text { Tampilan Map } \\
\text { Beserta keterangan } \\
\text { lokasi }\end{array}$ & 3 & 6 & 4 & 2 & - & $(5 \times 3)+(4 \times 6)+(3 \times 4)+(2 \times 2)$ & 55 \\
\hline 3 & $\begin{array}{l}\text { Notifikasi saat } \\
\text { pengoperasian sistem }\end{array}$ & 6 & 5 & 4 & - & - & $(5 \times 6)+(4 \times 5)+(3 \times 4)$ & 62 \\
\hline 4 & $\begin{array}{l}\text { Respon sistem dalam } \\
\text { mengambil lokasi } \\
\text { secara online }\end{array}$ & 6 & 5 & 4 & - & - & $(5 \times 6)+(4 \times 5)+(3 \times 4)$ & 61 \\
\hline
\end{tabular}

Pernyataan diberikan dalam lima pilihan skala untuk kategori penilaian, yaitu: $5=$ sangat baik, $4=$ baik, $3=$ cukup baik, 2 = kurang baik, dan 1 = tidak baik.

Tabel 4 Hasil Penilaian Variabel kinerja sistem

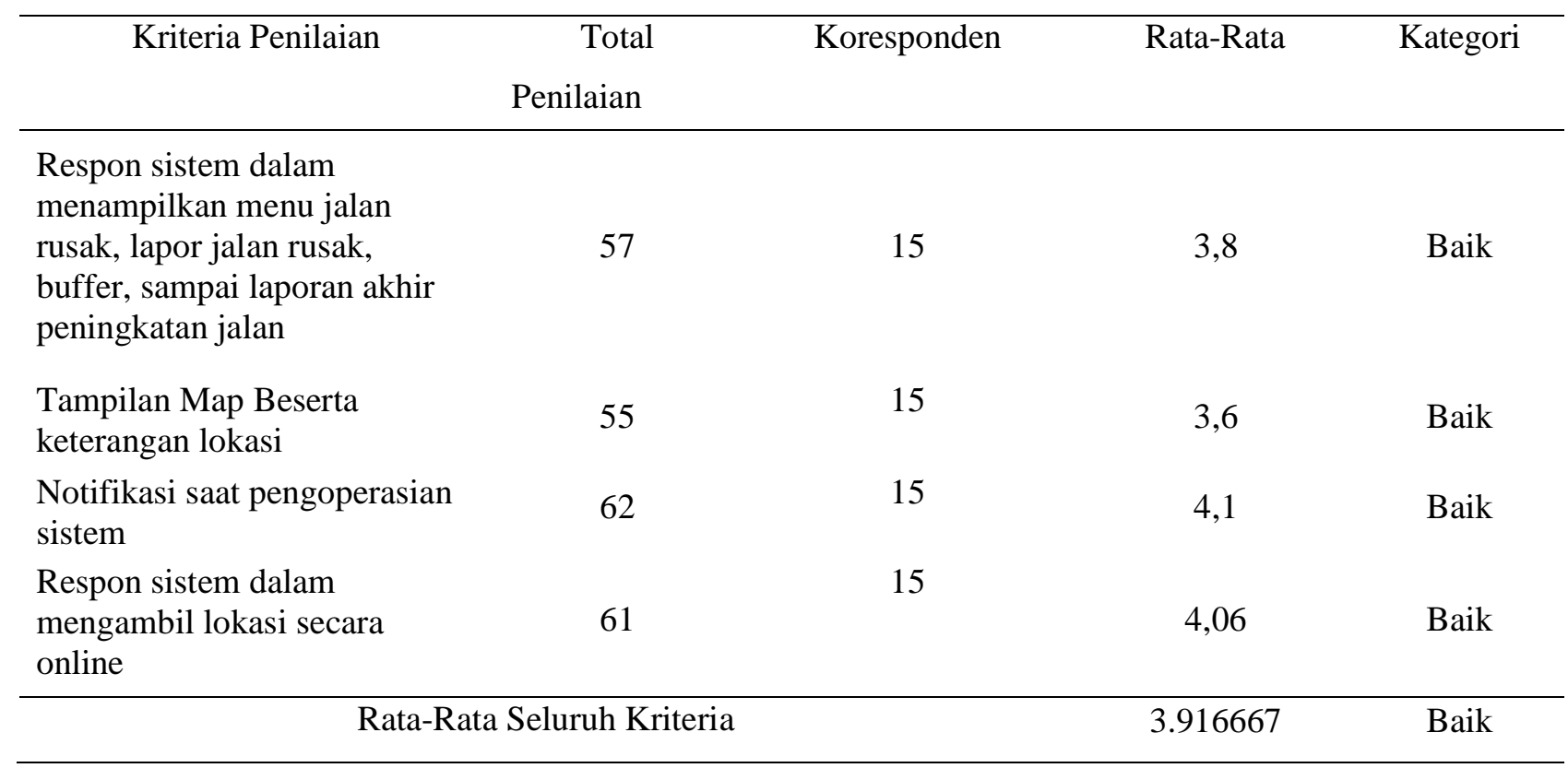

\subsubsection{Variabel User Friendly}

Pengujian pada Variabel user interface ini menggunakan kuesioner yang berisi beberapa Pernyataan.kuesioner yang diberikan kepada 15 orang koresponden, Hasil pengujian User Interface disajikan pada Tabel 5 dan Tabel 6. 
(C2021 Ilmu Komputer Unila Publishing Network all rights reserved

Tabel 5 Jumlah penilaian kategori User Friendly pada 15 koresponden

\begin{tabular}{|c|c|c|c|c|c|c|c|c|}
\hline \multirow{2}{*}{ No } & \multirow{2}{*}{ Kriteria Penilaian } & \multicolumn{5}{|c|}{ Kategori Penilaian } & \multirow[t]{2}{*}{ Jumlah penilaian } & \multirow{2}{*}{ Total } \\
\hline & & 5 & 4 & 3 & 2 & 1 & & \\
\hline 1 & $\begin{array}{l}\text { Respon } r \text { sistem } \\
\text { dalam menampilkan } \\
\text { tiap menu pada } \\
\text { sistem }\end{array}$ & 3 & 5 & 7 & - & - & $(5 \times 3)+(4 \times 5)+(3 \times 7)$ & 56 \\
\hline 2 & $\begin{array}{l}\text { Tampilan Map } \\
\text { Beserta keterangan } \\
\text { lokasi }\end{array}$ & 3 & 2 & 10 & - & - & $(5 \times 3)+(4 \times 2)+(3 \times 10)$ & 5 \\
\hline 3 & $\begin{array}{l}\text { Notifikasi saat } \\
\text { pengoperasian } \\
\text { sistem }\end{array}$ & 2 & 6 & 6 & 1 & - & $(5 \times 2)+(4 \times 6)+(3 \times 6)+(2 \times 1)$ & 54 \\
\hline 4 & $\begin{array}{lr}\text { Respon } & \text { sistem } \\
\text { dalam mengambil } \\
\text { lokasi secara online }\end{array}$ & 10 & 5 & - & - & - & $(5 \times 10)+(4 \times 5)$ & 55 \\
\hline
\end{tabular}

Pernyataan diberikan dalam lima pilihan skala untuk kategori penilaian, yaitu: $5=$ sangat baik, 4 = baik, $3=$ cukup baik, 2 = kurang baik, dan 1 = tidak baik.

Tabel 6 Jumlah penilaian kategori User Friendly pada 15 koresponden

\begin{tabular}{|c|c|c|c|c|}
\hline Kriteria Penilaian & $\begin{array}{c}\text { Total } \\
\text { Penilaian }\end{array}$ & Koresponden & Rata-Rata & Kategori \\
\hline $\begin{array}{l}\text { Kemudahan dalam mengakses } \\
\text { aplikasi secara online }\end{array}$ & 56 & 15 & 3,7 & Baik \\
\hline $\begin{array}{l}\text { Kejelasan informasi dalam } \\
\text { pengoperasian } \\
\text { sistem }\end{array}$ & 5 & 15 & 3,5 & Baik \\
\hline $\begin{array}{l}\text { Kemudahan dalam } \\
\text { mengoperasikan aplikasi }\end{array}$ & 54 & 15 & 3,6 & Baik \\
\hline $\begin{array}{l}\text { Kemudahan informasi yang } \\
\text { disajikan pada sistem }\end{array}$ & 55 & 15 & 3,6 & Baik \\
\hline Rata-Rata & Iuruh Kriteria & & 3.633333 & Baik \\
\hline
\end{tabular}

Berdasarkan 3 aspek Analisis Pengujian yang telah diketahui masing-masing nilai dan kategorinya, disimpulkan bahwa SIG kerusakan dan kegiatan peningkatan jalan di kota Bandar Lampung telah berjalan sesuai dengan fungsinya dan berkategori baik. nilai rata-rata keseluruhan pengujian disajikan pada Tabel 7 . 
(C2021 Ilmu Komputer Unila Publishing Network all rights reserved

Tabel 7 Hasil Penilaian Keseluruhan

\begin{tabular}{|c|c|c|c|c|}
\hline Variabel & $\begin{array}{c}\text { User } \\
\text { Interface }\end{array}$ & $\begin{array}{l}\text { Kinerja } \\
\text { Sistem }\end{array}$ & $\begin{array}{c}\text { User } \\
\text { Friendly }\end{array}$ & Kategori \\
\hline Seluruh & 3.816667 & 3.916667 & 3.633333 & Baik \\
\hline Rata-Rata Keseluruhan & & 3.788889 & & Baik \\
\hline
\end{tabular}

\section{KESIMPULAN}

Berdasarkan hasil penelitian yang telah dilakukan, diperoleh kesimpulan yaitu telah berhasil dibuat aplikasi berbasis web yang dapat memberikan informasi detail lokasi jalan rusak yang terdiri dari titik koordinat, keterangan kerusakan jalan, dan foto jalan yang dilaporkan serta biodata pelapor. Aplikasi berbasis mobile juga telah berhasil dibuat dengan fokus yaitu unutuk memasukkan data pelaporan jalan rusak. Berdasarkan Hasil Kuesioner Telah disimpulkan bahwa SIG Pelaporan jalan Rusak dan Aplikasi Mobile yang dikembangkan berjalan dengan baik.

\section{DAFTAR PUSTAKA}

[1] Dyah,Nur Rochmah. 2015. sistem informasi geografis tempat praktek dokter spesialis di provinsi d.i. yogyakarta berbasis web. Yogyakarta : Universitas Ahmad Dahlan.

[2] Kurniawati, Dwi P .2014. Sistem Informasi Geografis kerusakan ruas jalan di kota Yogyakarta. Yogyakarta : UIN Sunan Kalijaga.

[3] Sumaja, gita larasati. 2013. Sistem Informasi Geografis (SIG) Pencarian Letak Titik Posisi Ruangan Perkuliahan di Universitas Widyatama. Bandung:Universitas Widyatama. 